\title{
Old Finds- New Insights: Remarks on two Roman LEAd ingots FRom Minas de Riotinto (Huelva, España)
}

\author{
Peter Rothenhoefer \\ Kommission für Alte Geschichte und Epigraphik des DAI \\ Michael Bode \\ Deutsches Bergbau-Museum Bochum \\ NORBERT HANEL \\ Archäologisches Institut, Universität zu Köln
}

Recibido: 09/09/2015

Revisado: 113/11/2015

RESUMEN

Los autores analizan dos lingotes de plomo romanas encontradas en Minas de Riotinto y sólo conocen por fotos antiguas. Ambos lingotes se pueden atribuir a un empresario involucrado en el negocio minero de Cartagena en la primera mitad del siglo primero a.C.
Aceptado: $30 / 03 / 2016$

Publicado: 30/06/2016
Palabras Clave

lingotes de plomo; messii; minería romana; riotinto; cartagena.
ABSTRACT

The authors analyze two Roman lead ingots found at Minas de Riotinto and only known by old photographs. Both ingots can be attributed to an entrepreneur involved in the mining business of Cartagena in the first half of the $1^{\text {st }}$ century BC.
KEYWORDS

lead ingots; messii; roman mining; rio tinto; cartagena

peter.rothenhoefer@dainst.de

michael.bode@bergbaumuseum.de

norbert.hanel@uni-koeln.de 
While discussing the findspot of El Castillejo (El Campillo) near Minas de Riotinto Juan Aurelio Pérez Macías and Aquilino Delgado Domínguez also described selected finds of Republican age from the mining area of Riotinto kept in the Museo Minero de Riotinto and the Museo de Huelva (Pérez Macías, Delgado Domínguez, 2011, 70-73). The authors mentioned among other objects two hitherto unknown lead ingots found at the "zona del Filón Norte". ${ }^{1}$ Both are only known by two black and white photos taken in 1904 (fig. 1 and 2), which are kept in the Archivo Histórico Minero de Fundación Río Tinto. The slightly overexposed pictures show round shaped ingots of Republican type typically for the Roman lead production of Cartagena. On their back each one has two small rectangular panels with moulded inscriptions and signs. One of the ingots (Inv. $n^{\circ}$. A-8 No 922) is damaged (fig. 1): the left end up to the beginning of the panel is cut off and more than a dozen (drilling?) holes can be seen on the back damaging also the left panel. The other ingot seems to be fully conserved (fig. 2), but the overexposure of the photo (Inv. $\mathrm{n}^{\circ}$. A-8 $\mathrm{N}^{\circ} 923$ ) makes it extremely difficult to read single letters of the moulded inscription in the left panel.

1 Furthermore two ingots, now lost, „con sello de Carthago Nova“(Pérez Macías, Delgado Domínguez, 2011, $70)$. These two ingots with the typical round shaped form of Republican lead ingots produced at the mines near Cartagena had been found at Riotinto in a slag pile. The correct reading of the stamp is Nova Carthago (Rickard, 1926/1927, 333; CILA I 46). - The wrong reading also in Domergue, 1966, 65 and in Millán, 1989, 126-127.

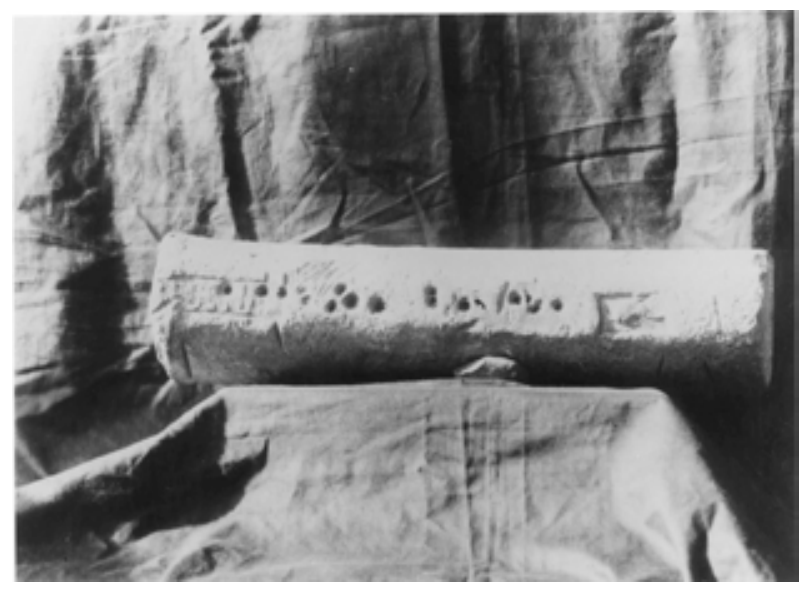

Fig. 1: Lead ingot, cut on the left, found at the zona del Filon Norte at Minas de Riotinto (Inv. nº. A-8 No 922). Archivo Histórico Minero de Fundación Río Tinto.
On both ingots there is a dolphin moulded in relief within the right panel. Therefore we can assume that in the left panel of each ingot the name of the same entrepreneur or of a societas could be read. Only the picture of the ingot with the cut off left end allows us to read greater parts of that name. J. A. Pérez and A. Delgado had observed "una $\mathrm{S}$ inicial, nexo AI y L final". They proposed to read S(ocietas) A(rgentaria) IL(ucronensis) (2011, 70; cf. Antolinos Marín et alii, 2013, 95 note 21). Apparently they think that it is the following societas known from moulded inscriptions on several lead ingots:

1) Lead ingot found in Rome $(46 \times 9 \times 10 \mathrm{~cm})$ with three rectangular panels on the back (CIL XV 7916; Antolinos Marín et alii, 2013, 96 fig. 7,2):

Societ(atis) argent(i) || fod(inarum) • mont(is or -ium) - Ilucr(onensis or -onensium) | galena

2) Five lead ingots found at Cabezo del Castillo, Mazarrón (province of Murcia) with three rectangular panels on the back (AE 1907, 135; Besnier 1920, $238 \mathrm{n}^{\circ}$. 15; Antolinos Marín et alii, 2013, 96 fig. 7,1$)$ :

Societ(atis) || mont(is or -ium) • argent(ifodinarum) | | Ilucr(onensium)

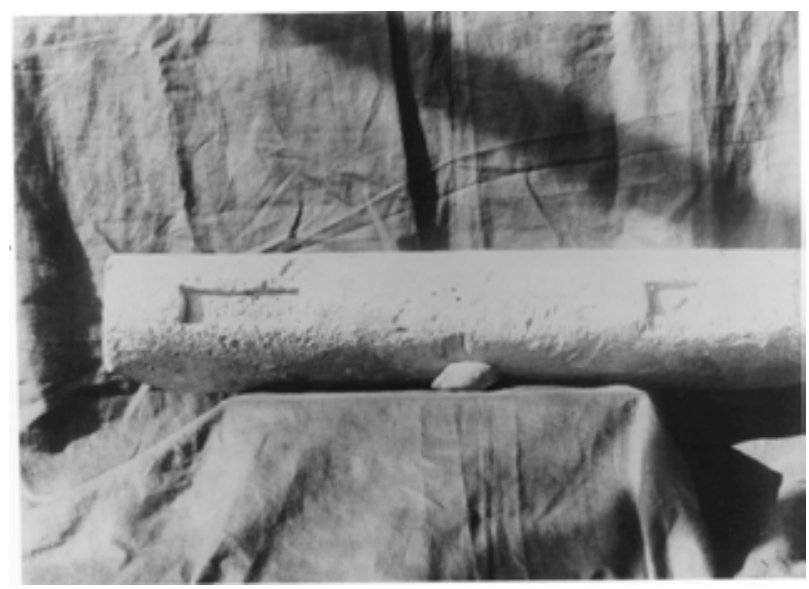

Fig. 2: Lead ingot found at the zona del Filon Norte at Minas de Riotinto (Inv. nº. A-8 No 923).

Archivo Histórico Minero de Fundación Río Tinto. 
3) Lead ingots from a newly discovered shipwreck near Messina (Sicily) with three panels on the back (Rothenhoefer et alii, forthcoming):

\section{Societ(atis) arg(enti-) || fod(inarum) mont(is) Ilucr(onensis vel -onensium) || [galena?]}

The name of that societas probably appears on small lead seals found at the Cabezo del Castillo, Mazarrón. There we read the very simple form $S \cdot A \cdot I=s$ (ocietatis) a(rgentifodinarum) $I(l u-$ cronensium) (Antolinos Marín et alii, 2013, 104112; Antolinos Marín, Díaz Ariño, 2012, 33-35). But on the ingots we always find a clearly longer version of that name. This observation together with the fact that there is no combination with the sign of a dolphin on those ingots causes doubts about the text proposed by J. A. Pérez and A. Delgado.

Indeed, a close view on the photo of the damaged ingot (Inv. $\mathrm{n}^{\circ} \mathrm{A}-8 \mathrm{~N}^{\circ}$ 922) allows to suggest another formular (fig. 3b): The first letter after the cut is damaged at the bottom, it must be an E or F. It is followed by double $\mathrm{S}$, after that the lower part of an I (the upper part destroyed by a drilling hole); the next letter clearly is L, followed by a vertical line. That means: [- - -]FSSILI or [- - -]ESSILI. The latter reading can be compared with names already documented on lead ingots: $C$ MESSI L F = C(aii) Messi(i) L(ucii) f(ilii) on one ingot found in Italy at Savignano del Rubicone (province of Forli-Cesena) (CIL 11, 6722, 13; Besnier, 1921, 109 and $127 \mathrm{n}^{\circ}$. 61; Davies 1935, 109 note 7; Ramallo Asensio, Berrocal Capparos, 1994, 125; Domergue, 1988, 213 tab. 1) and on another ingot found in the wreck Bajo de Dentro at Cabo de Palos (province of Murcia), which is now kept in the Museo Naval in

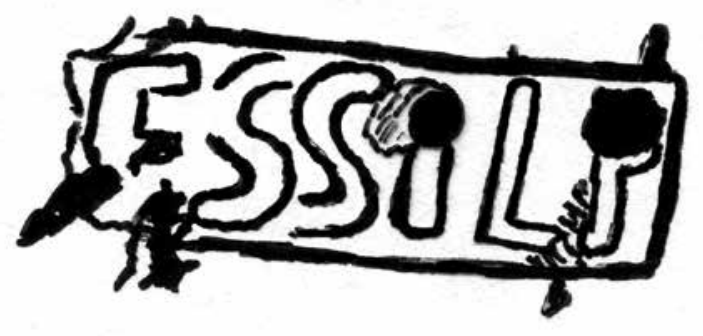

Fig. 3: Drawings of the moulded inscriptions: a) ingot from Bajo de Dentro (Museo Naval, Madrid); b) of the damaged ingot from photo Inv. $\mathrm{n}^{\circ}$. A-8 No 922.

P. Rothenhoefer/J. Hollaender.

Madrid (Inv. $n^{\circ} .1061$ ) (fig. 4) (Domergue, 1966, 48 - 50. 53 fig. 2,3. 3; Id., 1990, 255 n. 1023; Abascal Palazón, Ramallo Asensio, 1997, 58; Díaz Ariño, 2008, 283 SP18. Cf. Domergue, 1988, 213 tab. 1). On the back of these ingots two panels can be observed, on the left a panel with a dolphin, on the right a panel with the name of the entrepreneur Caius Messius (fig. 3a). That the name appears in the second panel is no obstacle to use it for the reconstruction of the two ingots from Riotinto.

The type of all four ingots is typical for the lead production in the area of Cartagena (cf. Domergue, 1966). This and the find spot at Cabo de Palos not far from Cartagena lead to the conclusion, that Caius Messius was active there. It is confirmed by lead isotope analyses, but unfortunately the lead isotope data provided by Pier Renato Trincherini and his collegues do not allow to safely distinguish whether the lead was produced inside the mining areas of La Unión or Mazarrón (Trincherini et alii, 2009, $129 \mathrm{n}^{\mathrm{os}}$. 22-23). That Messii had been present in

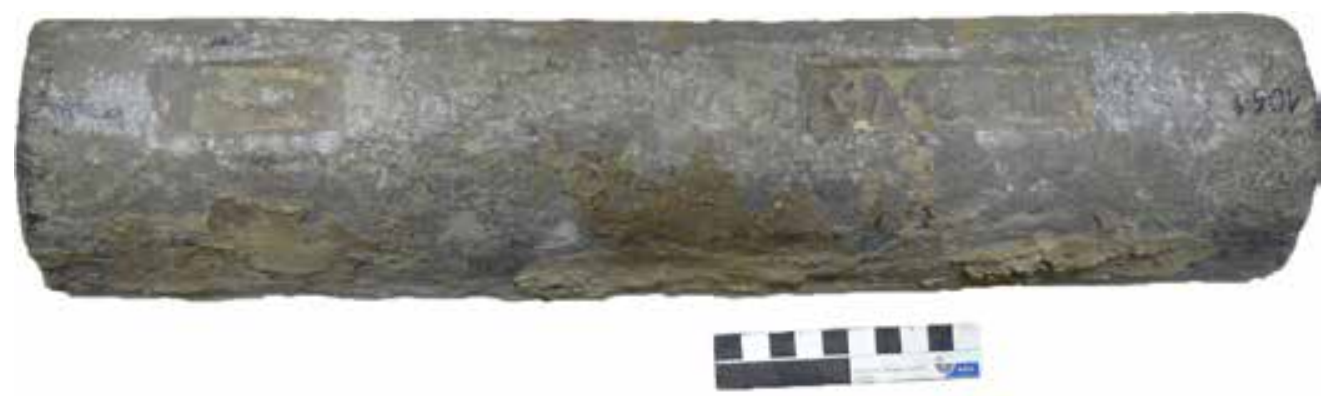

Fig. 4: Lead ingot of C. Messius found at Bajo de Dentro (Museo Naval, Madrid).

P. Rothenhoefer/Archiv CMPR. 
Roman Cartagena is confirmed by epigraphic evidence: Marcus Messius Samalo, freedman of Marcus, died there during the reign of Augustus (AE 1977, 458; Abascal Palazón, Ramallo Asensio, 1997, 369$371 \mathrm{n}^{\circ}$. 153). Although no direct line between Caius Messius, who had been engaged in the metal business in the first half of the $1^{\text {st }}$ century $\mathrm{BC}$, and the patron and former owner of Samalo, Marcus Messius, can be drawn, we can assume that members of the Messii played an active role in the economic life of Cartagena. Already Claude Domergue, following Friedrich Münzer, pointed out that the origins of the gens Messia can be localized in Campania (Domergue, 1966, 50 and 64; Koch, 1978, 257. Cf. Münzer, 1931). Recently, Michele Stefanile draw our attention to Northern Campania as the area of origin of that gens (Stefanile, 2015, 174). There is no doubt that Caius Messius or his predecessors moved to Cartagena - as did e. g. members of the families of the Atellii, Carulii, Nonae, Planii, Seii and Utii - and started to take part in the booming metal business ( $c f$. Domergue, 1990, 321-322; Stefanile 2015).

In his first article on the lead ingots kept in the Museo Naval at Madrid, C. Domergue suggested a date "entre 140 av. J.-C. et la période augustéenne", and more than 20 years later he gave a date a little bit more limited between the "fin de $\mathrm{II}^{\mathrm{e}}$ siècle et première moitié du Ir siècle avant J.-C." (Domergue, 1966, 67; Id., 1990, 265). Similiar is the date suggested by Borja Díaz Ariño (2008, 283): "El sello puede fecharse hacia mediados del siglo I a.e.”. In our opinion, it is possible to give a more precise dating range. In the ship wreck Bajo de Dentro, together with the C. Messius-ingot, lead of the following entrepreneurs had been found: Marcus Aquinius, son of Caius; Marcus and Sextus Calvius, sons of Marcus; Caius Utius, son of Caius; Lucius Planius Russinus, son of Lucius. The names of those entrepreneurs also appear on lead ingots from several other wrecks more or less well dated:

From a ship sunken near the small island of Mal di Ventre (A) (province of Oristano, Sardinia) in front of the Western shore of Sardinia, ingots have been discovered inter alia with the names of $\mathrm{M}$. Aquinius C. f., L. Planius L. f. Russinus, M. and Sex. Calvius M. f. and C. Utius C. f. Donatella Salvi dated the wreck "fra 1'89 a.C. - anno in cui la lex Iulia inserisce gli Italici nelle tribù urbane - e la metà del secolo" (Salvi, 1992 a, 247; cf. Salvi 1992 b, 673), while A. Mastino et alii suggested the years around 90/80 BC. (Mastino et alii, 2005, $217 \mathrm{n}^{\circ}$. 38). A younger date "a mediados del siglo I a.e." has been favored by Anthony J. Parker, C. Bigagli and B. Díaz Ariño (Parker, 1992, 255-256 n. 637; Bigagli, 2002, 171; Díaz Ariño 2008, 276). Actually, the Mal di Ventre (A) wreck seems to have been sunken around $80-50 \mathrm{BC}$.

The ship wreck Madrague de Giens (Département Var, F) had at least one ingot on board that bears the name C. Utius C. f. (in nominative case!) (AE 1976, 385 b; Laubenheimer 1978, 70-71 n. 3 with pl. 24,3 and 25,2). It is dated to around $60-50$ BC (Tchernia et alii, 1978, 15-17; Parker, 1992, 249_ 250 cat. $n^{\circ}$. 616; Treister, 1996, 349 n. 12; Brown 2011, $\left.216 n^{\circ} .23\right)$. Only B. Díaz Ariño (2008, 275) pleads for a higher date "entre el 75 y el 60 a.e."

The famous ship wreck from Mahdia (Tunisia) can be linked by ingots of L. Planius L. f. Russinus (Besnier, 1921, 101. 127 n. 56; Domergue, 1965, 13 pl. 2 a; Eck, 1994, 91-92 n. 9-10, fig 9-10; Brown, 2011, 212 no. 20.9-20.10) with the ship wreck Bajo de Dentro. While the former dating to 100-80 BC must be rejected as too early, depending on the analysis of the youngest ceramic finds, the sinking of the Mahdia ship approximately took place within or shortly after the years of 80 to $65 \mathrm{BC}$ (Rotroff, 1996, 274-275; Brown, 2011, 210 n 20 [80-70 B.C.E.]; $c f$. Díaz Ariño 2008, 276: "en la primera mitad del siglo I a.e.”).

Also the ship wreck of Ventotene (province of Latina, Italy) can be connected by ingots of C. Utius with the ship wreck of Bajo de Dentro (Gianfrotta, 1986, 217 fig. 371-372; Brown, 2011, 209 $\mathrm{n}^{\circ}$. 18; Ritondale, 2014, 28; Stefanile, 2014, 71-73). The dating of this ship is comparable to the previous ones (Gianfrotta, 1986, 217; Parker, 1992, $351 \mathrm{n}^{\circ}$. 932), which means that all mentioned ship wrecks and the ingots of the entrepreneur C. Messius can be dated into the second quarter of the $1^{\text {st }}$ century BC. ${ }^{2}$

With these two ingots of $\mathrm{C}$. Messius the number

2 The following ship wrecks offshore Sardinia have a similar dating: Punta Falcone, province of Sassari (Bonello Lai, 1986/1987; Parker, 1992, 353 nº. 939; Treister, 1996, 349 nº. 13; Bigagli, 2002, 172-173; Mastino et alii, 2005, $228 \mathrm{n}^{\circ} .71$; Brown, 2011, $218 \mathrm{n}^{\circ}$. 26), Capo Testa B, province of OlbiaTempio (Gandolfi, 1986, 86-88 note 14, fig. 11-12, 15; Bonello Lai, 1986/1987, 37 nº. 1-2; AE 1989, 349 b; Bigagli, 2002, 162163 fig. 4,1-4,2; Mastino et alii, 2005, 231-232 n ${ }^{\circ}$. 83; Brown 2011, $215 \mathrm{n}^{\circ}$. 22.1-22.2) and Capo Mannu, province of Sassari, where 13 lead ingots have been recovered (unpublished; stored at the Centro di Restauro, Li Punti, Sassari). 


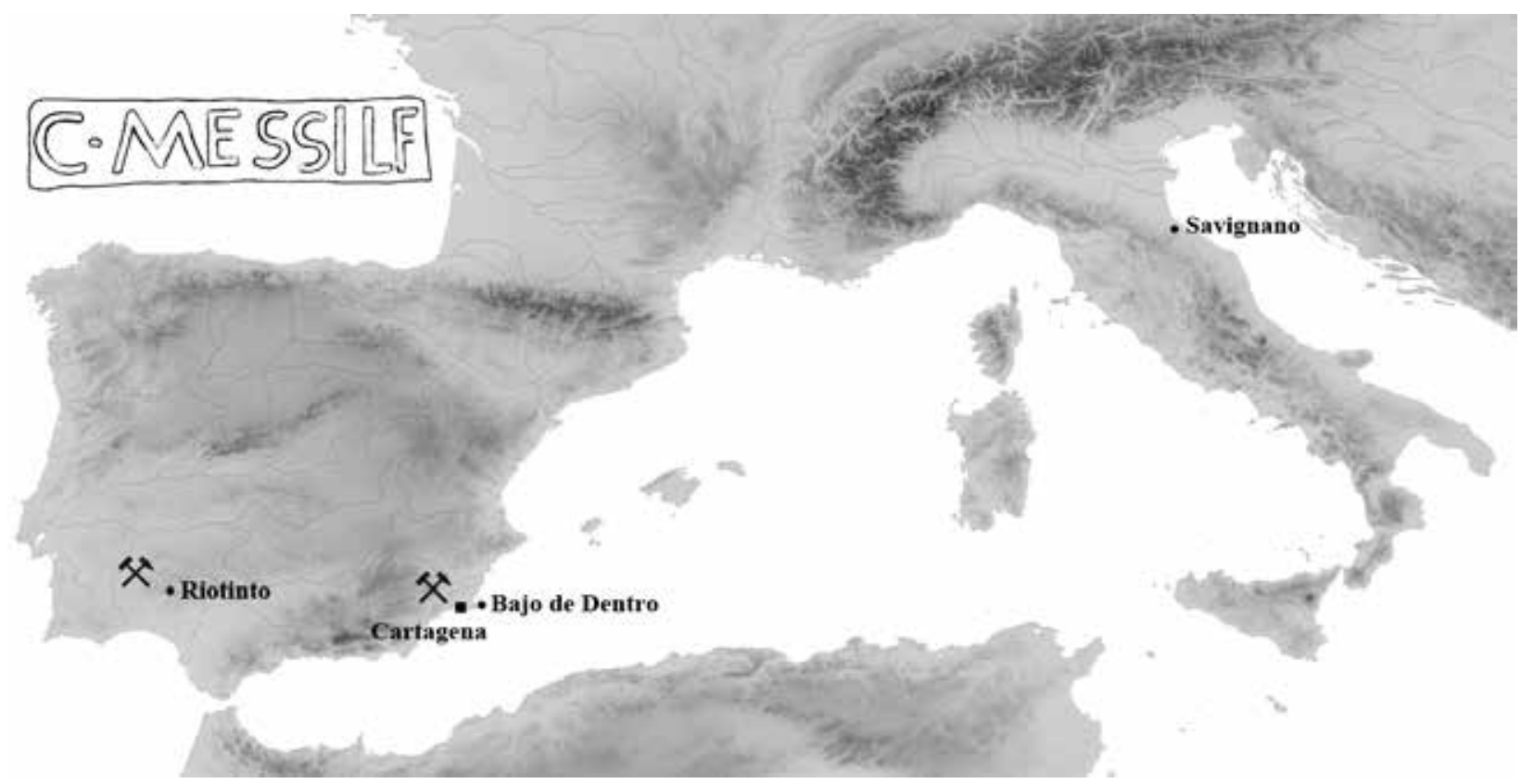

Fig. 5: Distribution map of ingots bearing the inscription of C. Messius.

P. Rothenhoefer/J. Hollaender.

of lead ingots from Cartagena found in the Riotinto mining district rises up to five: Besides the two now lost - ingots with the stamp Nova Carthago there is one more ingot from the mine El Soldado at El Palomino (Aracena, province of Huelva), on which one can read the name of L. Aurunc(uleius?) $\mathrm{Ta}(---)$, freedman of Lucius (CILA I 52; Díaz Ariño, 2008, 279 SP8; Trincherini et alii, 2009, $128 \mathrm{n}$. 7-8.). If one takes into consideration that only a very small percentage of ingots survived over the times, we have to assume that already in the second quarter of the $1^{\text {st }}$ century $\mathrm{BC}$ great quantities of lead from Cartagena have been transported to the mines of Riotinto. ${ }^{3}$

As Paul T. Craddock, Ian C. Freestone, Noél H. Gale, Nigel D. Meeks, Benno Rothenberg and Michael S. Tite pointed out, for the silver production at Riotinto lead had a crucial role already in the

first step of the production (Craddock et alii, 1985; Anguilano et alii, 2010). Because of its role as a sil-

3 Another ingot with three round stamps showing pentagrams was also found within layers of the $1^{\text {st }}$ century BC in the "Filón Norte" at Minas de Riotinto (Huelva, Museo Provincial Inv.-n ${ }^{\circ}$. A./D.J. ${ }^{\circ}$. 5495; Pérez Macías, Delgado Domínguez, 2011, 70; 72-73 pl. 9,7-8). Due to typological reasons a provenance from mines of the Cartagena district is unlikely. ver collector lead was "periodically sprinkled" into the furnace. During a later step of production, the silver could be won by cupellation.

The two lead ingots bearing the name of $\mathrm{C}$. Messius give evidence that intense trading connections between the lead-silver mines near Cartagena and the Riotinto mining district north of Huelva already had been established in the second quarter of the first century BC. They are also important documents for the interconnectivity of Roman mining areas in Hispania in Republican time.

\section{BIBLIOGRAPHY}

$\mathrm{AE}=\mathrm{L}^{\prime}$ Année Épigraphique.

$\mathrm{CIL}=$ Corpus Inscriptionum Latinarum.

CILA = Corpus de inscripciones latinas de Andalucía.

Abascal Palazón, J. M., Ramallo Asensio, S. F. (1997), La ciudad de Carthago Nova: la documentación epigráfica, Murcia.

Anguilano, L., Rehren, Th., Müller, W., Rothenberg, B. (2010), "The importance of lead in the silver production at Riotinto (Spain) ", ArcheoSciences 34, 269-276.

Antolinos Marín, J. A., Díaz Ariño, B. (2012), "La societas argentifodinarum Ilucronensium y la explotación de las minas romanas de Carthago 
Nova", Chiron 42, 25-43.

Antolinos Marín, J. A., Díaz Ariño, B., Guillén Riquelme, M. C. (2013), "Minería romana en Carthago Nova: el Coto Fortuna (Murcia) y los precintos de plomo de la Societas Argentifodinarum Ilucronensium”, JRA 26, 88-121.

Bachmann, H.-G. (1977), Bleiglätte-Fund aus der Nordeifel, Bonner Jahrbücher 177, 617-622.

Besnier, M. (1920), "Le commerce du plomb a l'époque romaine d'après les lingots estampillés", $R A$ Ser. 5, 12, 211-244.

Besnier, M. (1921), "Le commerce du plomb a l'époque romaine d'après les lingots estampillés”, $R A$ Ser. 5, 14, 1921, 98-130.

Bigagli, C. (2002), "Il commercio del piombo ispanico lungo le rotte attestate nel bacino occidentale del Mediterraneo", Empúries 53, 155-194.

Bonello Lai, M. (1986/1987), "Pani di piombo rinvenuti in Sardegna", Studi sardi 27, 7-39.

Brown, H. G. (2011), A study of lead ingot cargoes from ancient Mediterranean shipwrecks, thesis A\&M University 2011, http://repository. tamu.edu/bitstream/handle/ 1969.1/ETD-TAMU-2011-08-10126/BROWN-THESIS.pdf; 14.5.2015. (Consulta 12-XII-2014).

Craddock, P. T., Freestone, I. C., Gale, N. H., Meeks, N. D., Rothenberg, B., Tite, M. S. (1985), "The investigation of a small heap of silver smelting debris from Rio Tinto, Huelva, Spain", Furnaces and Smelting Technology in Antiquity, BMOccasP 48 (Craddock, P. T. and Hughes, M. J., eds.), London, 199-217.

Davies, O. (1935), Roman Mines in Europe, Cambridge.

Díaz Ariño, B. (2008), Epigrafía latina republicana de Hispania (ELRH). Collecció Instrumenta 26, Barcelona.

Domergue, C. (1965), "Les Planii et leur activité industrielle en Espagne sous la République", MelCasaVelazquez 1, 9-25.

Domergue, C. (1966), "Los lingots de plomb romains du Musée Archéologique de Carthagène et du Musée Naval de Madrid”, AEspA 39, 4172.

Domergue, C. (1988), "L'exploitation des mines d'argent de Carthago Nova: son impact sur la structure sociale de la cite et sur les dispensées locales a la fin de la republique et au debut du Haut-Empire", L'origine des richesses d'pensées dans la ville antique. Actes du colloque organisé à Aix-en-Provence par
l'U.E.R. d'Histoire, les 11 et 12 Mai 1984

(Leveau, Ph., ed.), Aix-en-Provence, 197-217.

Domergue, C. (1990), Les mines de la Peninsule Iberique dans l'Antiquité Romaine, Rom.

Eck, W. (1994), "Die Bleibarren”, Das Wrack. Der antike Schiffsfund von Mahdia. Katalog Rheinisches Landesmuseum Bonn 1,1 (Hellenkemper-Salies, G., von Prittwitz und Gaffron, H.-H., Bauchhenß, G., eds.), Köln, 89-95.

Gandolfi, D. (1986), "Il relitto di Capo Testa", $A r$ cheologia subacquaea 3. BdA Suppl. 37/38, 81-88.

Gianfrotta, P. A. (1986), "Rinvenimenti archeologici sottomarini", Le isole pontine attraverso i tempi (De Rossi, G. M., ed.), Rom, 212-222.

Koch, M. (1978), "Neue römische Inschriften aus Carthago Nova II", Madrider Mitteilungen 19, 251-262.

Laubenheimer, F. (1978), "Les ingots de plomb", L'épave romaine de la Madrague de Giens (Var). Campagnes 1972-1975 (Tchernia, A., Pomey, P., Hesnard, A., eds), Gallia Suppl. 34, Paris, 69-72.

Mastino, A., Spanu, P. G., Zucca, R. (2005), Mare Sardum. Merci, mercati e scambi marittimi della Sardegna antica. Collana del Dipartimento di Storia del'Università degli Studi di Sassari 26, Rome.

J. Millán León, J. (1989), Ilipa Magna, Écija.

Münzer, F. (1931), Messius, RE XV 1, 1242, Stuttgart.

Parker, A. J. (1992), Ancient shipwrecks of the Mediterranean and the Roman provinces. BAR Int. Ser. 580, Oxford.

Pérez Macías, J. A. and Delgado Domínguez, A. (2011),"El castellum de el Castillejo (El Campillo, Huelva): La explotación romano-republicana en Riotinto", Río Tionto. Historia, patrimonio minero y turismo cultural (Pérez, J. A., Delgado, A., Pérez, J. M., García, F. J., eds.), Huelva, 47-73.

Ramallo Asensio, S. F., Berrocal Capparos, M. C. (1994), "Minería púnica y romana en el sureste peninsular: el foco de Carthago Nova”, Minería y metalurgía en la España prerromana y romana. Actas de los Seminarios de verano "Fons Mellaria 1992" (Fuenteovejuna, Córdoba) (Vaquerizo Gil, D., ed.), Córdoba, 79-146.

Rickard, T. A. (1926/1927), mentioned in Palmer, R. E., "Notes on some Ancient Mine Equipments and Systems", Transactions of the 
Institution of Mining and Metallurgy, 36, 299-336.

Ritondale, M. (2014), “Deep discoveries from the seabed of Pontine Islands: the shipwrecks of Ventotene, S. Stefano and Zannone", Assemblage 13, 26-38.

Rothenhoefer, P., Tisseyre, Ph., Hanel, N., Bode, M. (forthcoming), "More ingots of the societas argentifodinarum montis Ilucronensis: New evidence for the distribution of metals in the 1st century BC", Epigraphica (forthcoming).

Rotroff, S. I. (1996), Reply to Marek Palaczyk, "Neue Überlegungen zur absoluten Datierung der Funde aus dem Schiffswrack von Mahdia" Bonner Jahrbücher 196, 271-275.

Salvi, D. (1992 a), "Cabras (Oristano). Isola di Mal di Ventre“, BA 16-18, 237-248.

Salvi, D. (1992 b), "Le massae plumbae di Mal di Ventre”, L'Africa romana. Atti del IX convegno di studio Nuoro, 13-15 dicembre 1991 (Mastino, A., ed.), Sassari, 661-672.

Stefanile, M. (2014), "Fiduii, Utii, Lucretii, Saufeii. Osservazioni epigrafiche su materiali provenienti dai fondali delle isole Pontine”, Archaeologia maritima mediterranea 11, 63-78.

Stefanile, M. (2015), "Gentes procedentes de Campania en la explotación de las minas de Carthago Nova”, Phicaria. Minería y metalurgia en el Mediterráneo y su periferia oceánica III encuentros internacionales del Mediterráneo (López Ballesta, J. M, coord.), Mazarrón, 170180.

Tchernia, A., Pomey, P., Hesnard, A. (1978), L'épave romaine de la Madrague de Giens (Var). Campagnes 1972-1975, Gallia Suppl. 34, Paris.

Treister, M. Yu. (1996), The role of metals in ancient Greek history. Mnemosyne Suppl. 156, Leiden, New York, Köln.

Trincherini, P. R., Domergue, C., Manteca, I., Nesta, A., Quarati, P. (2009),"The identification of lead ingots from the Roman mines of Cartagena: the role of lead isotope analysis", JRA 22, 123-145. 
